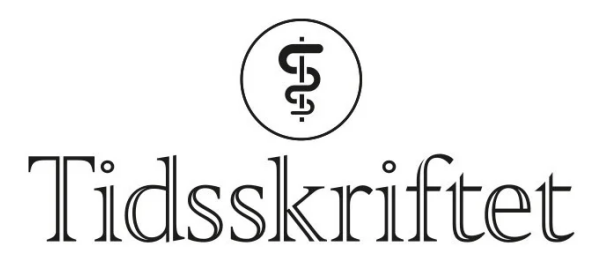

DEN NORSKE LEGEFORENING

\title{
Miljøgifter i norsk mat
}

\author{
DEBATT
}

\section{HENRIK S. HUITFELDT}

henrik.huitfeldt@medisin.uio.no

Henrik S. Huitfeldt er overlege ved Avdeling for patologi, Oslo universitetssykehus og professor ved Universitetet i Oslo.

Forfatteren har fylt ut ICMJE-skjemaet og oppgir ingen interessekonflikter.

\section{BJ $\varnothing R N$ J. BOLANN}

Bjørn J. Bolann er spesialist i medisinsk biokjemi, professor emeritus ved Klinisk institutt 2, Universitetet i Bergen og pensjonert overlege fra Avdeling for medisinsk biokjemi og farmakologi, Haukeland universitetssjukehus.

Forfatteren har fylt ut ICMJE-skjemaet og oppgir ingen interessekonflikter.

\section{Miljøgifter fører til kreft, utviklingsforstyrrelser hos barn og nedsatt fruktbarhet. I Norge ligger inntaket av dioksinliknende miljøgifter gjennom kosten til dels betydelig over EUs grenseverdier for trygt inntak. Hva vil myndighetene gjøre for å redusere befolkningens inntak av giftstoffer?}

Miljøgifter har mange skadelige effekter på helsen. Leger har i liten grad engasjert seg i dette, til tross for at miljøgifter i mat har fått mye medieoppmerksomhet. Særlig har persistente organiske miljøgifter (persistent organic pollutants, POP-er) skapt helsemessig bekymring. Disse omfatter dioksiner, polyklorerte bifenyler (PCB), enkelte pesticider og halogenerte flammehemmere. Dette er fettløselig landbruks- og industriforurensning som anrikes i fettvev og bioakkumulerer i lange næringskjeder, spesielt i havet.

«Myndighetene tillater mye høyere nivåer av slike miljøgifter $i$ sjømat enn $i$ annen mats

Selv om mange av de persistente organiske miljøgiftene ikke lenger er tillatt produsert, vil eksponeringen vedvare i mange tiår, da de brytes ned meget langsomt. Vi eksponeres alt overveiende gjennom maten, og nivåene er særlig høye i fettrik sjømat. Myndighetene 
tillater mye høyere nivåer av slike miljøgifter i sjømat enn i annen mat (11). Fisk og annen sjømat står for over 40 \% av eksponeringen i Norge, mens om lag $25 \%$ kommer fra meieriprodukter (2) .

\section{Undervurdert skadepotensial}

Selv i svært lave konsentrasjoner kan persistente organiske miljøgifter forårsake helseskader (3). Mange er kategorisert som karsinogene, de er immunhemmende, gir reproduksjonsproblemer og utviklingsforstyrrelser. Epidemiologiske undersøkelser har vist at barn av den delen av befolkningen som har høye nivåer av persistente organiske miljøgifter har vesentlig høyere risiko for forstyrret kognitiv utvikling, ADHD-liknende symptomer og læringsproblemer (4). Epidemiologiske undersøkelser viser også en sammenheng mellom eksponering for slike miljøgifter i dagens nivåer og fedme, type 2diabetes og andre metabolsk syndrom-assosierte helseeffekter, både hos barn og voksne (5, 6). Eksponeringer i dagens nivåer fører også til forringet sædkvalitet og nedsatt fertilitet hos menn (7.). Det er spesielt bekymringsverdig at disse negative helseeffektene påvises allerede ved dagens eksponeringsnivåer.

Mattilsynet og dets vitenskapskomité for mat og miljø (VKM) har avgitt flere rapporter om denne type miljøgifter i fisk og sjømat (ㅁ․,9.). Gjennom flere tiår har vi blitt forsikret om at nivåene i Norge ikke representerer noen helserisiko, at de ligger godt under anbefalingene fra European Food Safety Authority (EFSA), og at grenseverdiene er satt med god sikkerhetsmargin. Likevel har uavhengige forskere og leger ved norske universiteter og sykehus lenge advart om at de vedtatte grenseverdiene har vært satt for høyt (10, (11)). Særlig stor har bekymringen vært for eksponeringen i de første leveår og for kvinner i fertil alder.

\section{Høyere grenseverdier enn EU}

En ny vurdering av helseeffektene av disse miljøgiftene i 2018 førte til at EUs mattilsyn

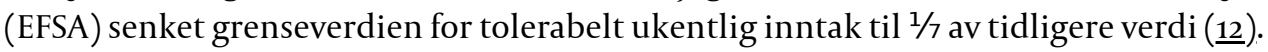
Flertallet av EUs befolkning konsumerer betydelig mer enn dette, og medianinntaket $\mathrm{i}$ Norge er nesten dobbelt så høyt som den nye grenseverdien $(\underline{\mathbf{1 2}}, \underline{13})$.

«Medianinntaket $i$ Norge er nesten dobbelt så høyt som den nye grenseverdien»

Mattilsynet har ikke synliggjort at også norske grenseverdier nå må senkes betydelig og at norske kostholdsråd må tilpasses den nye kunnskapen. Fremdeles promoteres et fiskekonsum som bidrar vesentlig til at man overstiger det tolerable ukentlige inntaket (14). Mattilsynet har bestilt to nye risikovurderinger fra Vitenskapskomiteen for mat og miljø for å vurdere risiko knyttet til dioksiner og dioksinliknende polyklorerte bifenyler (dl-PCB) i maten til den norske befolkningen (15). Men snart tre år senere foreligger ennå ikke vurderingene, og det synes som om Mattilsynet fremdeles forholder seg til de gamle grenseverdiene ( $\underline{16})$.

Mange har stilt spørsmål om Mattilsynets og Vitenskapskomiteen for mat og miljøs vurderinger av helse er preget av ikke-transparente, næringspolitiske føringer (17.). Samtidig har forvaltning og forskningsråd over flere tiår nedprioritert fagområdet miljømedisin. Derfor er det nå få uavhengige forskningsmiljøer som kan korrigere eller supplere Mattilsynets vurderinger. EUs nye grenseverdi anskueliggjør at befolkningens eksponering er uakseptabelt høy, og dette bør anspore norske myndigheter til å innføre reelle og offensive tiltak der det er mulig. En forpliktende plan for gradvis skjerping av 
grenseverdiene for mat og fôr, krav til rensing av ingredienser i fôr der dette er mulig, merking av matvarer med høye nivåer samt etablering av mer uavhengig, målrettet forskning omkring disse toksikologiske problemstillingene er mulige og gode tiltak. Inntil det skjer, må kostholdsrådene tilpasses dagens virkelighet, slik at befolkningens inntak av giftstoffer reduseres til et forsvarlig nivå. Dette, sammen med en mindre næringsfokusert og mer forsknings- og helsebasert forvaltning av utfordringene ved persistente organiske miljøgifter, vil også kunne styrke befolkningens tillit til de rådene som gis.

\section{LITTERATUR}

1. EU-kommisjonen. Commission Regulation (EC) No 1881/2006 of 19th December 2006 setting maximum levels for certain contaminants in foodstuffs. https://eur-

lex.europa.eu/LexUriServ/LexUriServ.do?uri=OJ:L:2006:364:0005:0024:EN:PDF Lest 5.7.2021.

2. Folkehelseinstituttet. Fakta om dioksiner og dl-PCB.

https://www.fhi.no/ml/miljo/miljogifter/fakta/dioksiner-og-dl-pcb-faktaark/ Lest 1.6.2021.

3. Carpenter DO. Polychlorinated biphenyls (PCBs): routes of exposure and effects on human health. Rev Environ Health 2006; 21: 1-23. [PubMed][CrossRef]

4. Schantz SL, Widholm JJ, Rice DC. Effects of PCB exposure on neuropsychological function in children. Environ Health Perspect 2003; 111:357-576. [PubMed][CrossRef]

5. Yang C, Kong APS, Cai Z et al. Persistent Organic Pollutants as Risk Factors for Obesity and Diabetes. Curr Diab Rep 2017; 17: 132-43. [PubMed][CrossRef]

6. Taylor KW, Novak RF, Anderson HA et al. Evaluation of the association between persistent organic pollutants (POPs) and diabetes in epidemiological studies: a national toxicology program workshop review. Environ Health Perspect 2013; 121: 774-83. [PubMed][CrossRef]

7. Mínguez-Alarcón L, Sergeyev O, Burns JS et al. A longitudinal study of peripubertal serum organochlorine concentrations and semen parameters in young men: the Russian Children's Study. Environ Health Perspect 2017; 125: 46o-6. [PubMed][CrossRef]

8. Vitenskapskomiteen for mat og miljø. Risk assessment of non dioxin-like PCBs in Norwegian food. VKM Report 2008: 14. https://ntnuopen.ntnu.no/ntnu-

xmlui/bitstream/handle/11250/2473920/ska\%25CC\%258Are_2008_Ris.pdf?sequence=2\&isAllowed=y Lest 5.7.2021.

9. Vitenskapskomiteen for mat og miljø. Benefit-risk assessment of fish and fish products in the Norwegian diet - an update. VKM Report 2014: 15.

https://vkm.no/download/18.2994e95b15cc54507161ea1a/1498222018046/oa646edc5e.pdf Lest 5.7.2021.

10. Huitfeldt HS. Er det trygt å spise laks? Kronikk. Aftenposten 11.3.2005.

11. Bolann BJ, Huber S, Ruzzin J et al. Er miljøgifter i norsk kosthold skadelig for barn? Tidsskr Nor Legeforen 2017; 137: 295-7. [PubMed][CrossRef]

12. Knutsen HK, Alexander J, Barregård L et al. Risk for animal and human health related to the presence of dioxins and dioxin-like PCBs in feed and food. EFSA J 2018; 16: e05333. [PubMed]

13. Papadopoulou E, Caspersen IH, Kvalem HE et al. Maternal dietary intake of dioxins and polychlorinated biphenyls and birth size in the Norwegian Mother and Child Cohort Study (MoBa). Environ Int 2013; 60: 209-16. [PubMed][CrossRef]

14. Nøstbakken OJ, Rasinger JD, Hannisdal R et al. Levels of omega 3 fatty acids, vitamin D, dioxins and dioxin-like PCBs in oily fish; a new perspective on the reporting of nutrient and contaminant data for risk-benefit assessments of oily seafood. Environ Int 2021; 147: 106322. [PubMed][CrossRef]

15. Matportalen.no. EFSA med ny vurdering av dioksiner og PCB i matvarer og fôr.

https://www.matportalen.no/uonskedestoffer_i_mat/tema/biologiske_gifter/efsa_med_ny_vurderin g_av_dioksiner_og_pcb_i_matvarer_og_fr Lest 1.6.2021.

16. Mattilsynet. Veileder om kjemiske forurensninger i mat.

https://www.mattilsynet.no/om_mattilsynet/gjeldende_regelverk/veiledere/veileder_om_kjemiske_ forurensninger_i_mat.34354/binary/Veileder\%200m\%2okjemiske\%2oforurensninger\%2oi\%2omat Lest 1.6.2021.

17. Harvest Magazine. Mørke krefter - en serie om sjømatnasjonen Norge.

https://www.harvestmagazine.no/serier/morke-krefter/ Lest 1.6.2021. 
Publisert: 4. august 2021. Tidsskr Nor Legeforen. DOI: 10.4045/tidsskr.21.0499

Mottatt 16.6.2021, godkjent 5.7.2021.

(C) Tidsskrift for Den norske legeforening 2023. Lastet ned fra tidsskriftet.no 26. april 2023. 